\title{
Systemic Lupus Erythematosus Presenting with Status Epilepticus: A Case Report
}

\author{
Status Epileptikus ile Birlikte Seyreden Sistemik Lupus Eritematozus: Olgu Sunumu \\ Faruk İNCECİK, M. Özlem HERGÜNER, Mustafa YILMAZ, Şakir ALTUNBAŞAK \\ Department of Pediatrics, Medical Faculty of Çukurova University, Division of Pediatric Neurology, Adana, Turkey
}

\begin{abstract}
Systemic lupus erythematosus is an autoimmune disorder involving multiple organs, including the nervous system. Neuropsychiatric involvement in systemic lupus erythematosus is one of the major manifestations of the disease. Both partial and generalised seizures can occur in patients with systemic lupus erythematosus. In this article, we report a seven-year-old girl with a case of systemic lupus erythematosus who initially presented with an episode of status epilepticus.
\end{abstract}

Key words: Pediatrics; status epilepticus; systemic lupus erythematosus.

Systemic lupus erythematosus (SLE) is a chronic autoimmune disease that produces numerous clinical symptoms. The clinical presentation and course of the disease can be quite variable. Several complications due to the involvement of the central nervous system (CNS), peripheral nervous system (PNS), and autonomic nervous system (ANS) along with psychiatric manifestations can be seen. ${ }^{[1,2]}$

Status epilepticus (SE) is defined as two or more sequential seizures without full recovery of consciousness between them, or continuous seizure activity lasting more than 30 minutes. It generally occurs as a manifestation of an acute precipitating event affecting the CNS or an exacerbation of symptomatic epilepsy. Slightly less than $10 \%$ of the
Sistemik lupus eritematozus, merkezi sinir sistemi dahil, çoklu organ tutulumu olan otoimmün bir hastalıktır. Sistemik lupus eritematozus hastalığında nöropsikiyatrik tutulum, hastalığın majör tanı kriterlerinden biridir. Sistemik lupus eritematozuslu hastalarda hem parsiyel hem de jeneralize nöbetler görülebilir. Bu yazıda, başlangıçta status epileptikus epizodu ile kendini gösteren sistemik lupus eritematozuslu yedi yaşında bir kız olgu sunuldu.

Anahtar sözcükler: Pediatrik; status epileptikus; sistemik lupus eritematozus.

cases are idiopathic. ${ }^{[3]}$ The mortality and morbidity rates of SE are high and are usually influenced by the underlying etiology. This clinical entity requires prompt management.

A young girl who had no initial history of seizure presented with SE, and in this case, the clinical clues or laboratory findings that implied the presence of SLE, except for anemia and seizures, were not found at admission. We herein report a case of SLE in a patient who first presented with SE.

\section{CASE REPORT}

A seven-year-old girl was admitted to the emergency room with SE. Her previous medical and family history were unremarkable, and her developmental milestones 
were normal. On admission, her vital signs and anthropometric measurements were within normal limits. The physical examination was unremarkable except for her unconscious state.

The initial laboratory results showed white blood cells of $4.8 \times 103 \mathrm{~mm}^{3}$, a platelet count of $238 \times 103 \mathrm{~mm}^{3}$, and a hemoglobin level of $8.8 \mathrm{~g} / \mathrm{dl}$. The serum electrolytes, metabolic screening of the urine and blood, lactic acid, and pyruvic acid as well as the renal and liver function tests were normal. A lumbar puncture revealed no white blood cells, and the protein and glucose levels were also normal. Serological studies revealed that the antinuclear antibody (ANA) and anti-dsDNA tests were negative. No evidence of viral, bacterial, or fungal infections was found on the results from the cerebral spinal fluid (CSF) and blood. Moreover, the toxicological studies were also negative. Brain magnetic resonance imaging (MRI) showed leptomeningeal enhancement without involvement of cerebral parenchyma. We administered intravenous acyclovir from the first day because herpes simplex encephalitis could not be excluded. An electroencephalography was performed which showed a generalized slowing of the background and epileptic activity in the left temporal region. Conventional antiepileptic drugs failed to control the seizures, and intravenous midazolam infusion was eventually started which stopped them. She was discharged with antiepileptic drugs.

During the six months after her discharge, she had several episodes of complex partial seizures, and her antiepileptic therapy was adjusted. Because she had had a generalized erythematous rash on her trunk and leg combined with a fever and oral ulcers for two weeks, she was hospitalized for reevaluation. Repeated laboratory tests were performed which revealed a positive ANA test, positive anti-dsDNA tests, pancytopenia, and proteinuria. A 24-hour urine collection showed proteinurea of $1.2 \mathrm{~g}$ serum C3 (normal range $90-180 \mathrm{mg} / \mathrm{dL}$ ) and C4 (normal range $10-40 \mathrm{mg} / \mathrm{dL}$ ) levels were 33.9 and $6.2 \mathrm{mg} / \mathrm{dL}$, respectively. A skin biopsy for immune histopathology showed leukocytoclastic vasculitis.

After confirming the diagnosis of SLE, she was treated with intravenous pulse methylprednisolone (20 mg/kg/day for three consecutive days), followed by oral prednisolone ( $1 \mathrm{mgr} / \mathrm{kg} /$ day $)$ therapy. The $\mathrm{C} 3$ and C4 levels returned to normal levels after treatment, and the proteinuria disappeared.

\section{DISCUSSION}

Systemic lupus erythematosus is a multisystem, autoimmune connective tissue disorder with a broad spectrum of clinical presentations. ${ }^{[4]}$ Central nervous system manifestations are a major cause of morbidity and, to a lesser extent, mortality in pediatric SLE. The prevalence of neuropsychiatric disease within SLE cohorts has been reported to vary from a low of $19 \%$ to a high of $95 \%$ of patients. ${ }^{[1]}$

Seizures have been documented in approximately $7-20 \%$ of SLE patients in children. ${ }^{[5,6]}$ Generalized tonic-clonic seizures are by far the most common, but simple partial seizures, complex partial seizures, and SE have also been described. ${ }^{[2,6,7]}$ These seizures can occur as single events or as part of epilepsy. Although seizures and epilepsy are relatively common in patients with SLE, SE is rare. Epileptic seizures can be a primary event resulting from the direct effect of active SLE manifestation in the CNS or occur independently of lupus activity itself, being associated with CNS infections, uremia, hypertension, or electrolyte disturbance. ${ }^{[1,6]}$

The diagnostic criteria for SLE requires that at least four characteristic features occur at any time during the disease course, but not necessarily simultaneously. Although these criteria were not fulfilled at this early stage, the later emergence of more typical features of the disease confirmed the diagnosis. Seizures are included as one of the 11 criteria applied to patients when attempting to diagnose SLE. ${ }^{[8]}$ Certainly, patients suffering from SLE are at higher risk of developing SE than the healthy population. Status epilepticus is an underrecognized emergency situation with substantial morbidity and mortality that requires immediate and effective treatment. It may be difficult to identify the etiology of SE at presentation. In literature, there have been patients who developed SE due to SLE. ${ }^{[6,7]}$ Park et al. ${ }^{[7]}$ reported a 17-year-old girl who developed SE at onset SLE. Appenzeller et al. ${ }^{[6]}$ reported that only two out of 519 patients with SLE had SE. Our patient presented with SE as the first manifestation of SLE. The notable findings in our patient were that the diagnosis of SLE was delayed due to negative initial laboratory results, and the initial manifestation of SLE was SE. The wholly nonspecific nature of these features helps explain why the clinical identification of CNS lupus remains in practice a serious diagnostic challenge, and this is complicated by the lack of specific laboratory tests, nonspecific neuroimaging findings, and inaccessible brain parenchyma for histological confirmation. 
The possibility of opportunistic infection in individuals who may well have received significant previous immune suppression also contributes to the extraordinarily difficult diagnostic problems in lupus patients with neurological involvement. For this present case, the classification criteria of SLE were fulfilled by neurological symptoms, rash, oral ulcer, pancytopenia, proteinuria, positive anti-DNA antibody, and positive ANA.

Epileptic seizures are particularly common at the beginning of SLE manifestations. An urgent electroencephalogram is essential to confirm an epileptic origin of the manifestations, which should be considered in differential diagnoses with unexplained and acquired clinical features resembling SE.

\section{Declaration of conflicting interests}

The authors declared no conflicts of interest with respect to the authorship and/or publication of this article.

\section{Funding}

The authors received no financial support for the research and/or authorship of this article.

\section{REFERENCES}

1. Benseler SM, Silverman ED. Neuropsychiatric involvement in pediatric systemic lupus erythematosus. Lupus 2007;16:564-71.

2. Greenberg BM. The neurologic manifestations of systemic lupus erythematosus. Neurologist 2009;15:115-21.

3. Knake S, Hamer HM, Rosenow F. Status epilepticus: a critical review. Epilepsy Behav 2009;15:10-4.

4. Hiraki LT, Benseler SM, Tyrrell PN, Hebert D, Harvey E, Silverman ED. Clinical and laboratory characteristics and long-term outcome of pediatric systemic lupus erythematosus: a longitudinal study. J Pediatr 2008;152:550-6.

5. Mackworth-Young CG, Hughes GR. Epilepsy: an early symptom of systemic lupus erythematosus. J Neurol Neurosurg Psychiatry 1985;48:185.

6. Appenzeller S, Cendes F, Costallat LT. Epileptic seizures in systemic lupus erythematosus. Neurology 2004;63:1808-12.

7. Park MH, Kwon DY, Yu JK, Seo WK. Delayed diagnosis of SLE in a patient presenting with intractable status epilepticus. Lupus 2009;18:474-5.

8. Tan EM, Cohen AS, Fries JF, Masi AT, McShane DJ, Rothfield NF, et al. The 1982 revised criteria for the classification of systemic lupus erythematosus. Arthritis Rheum 1982;25:1271-7. 